\title{
IL-4 Counteracts the Cytotoxic Effects of Peripheral Blood Mononuclear Cells on Hormone-sensitive Prostate Cancer Cells
}

\author{
HOLGER H.H. ERB ${ }^{1,2}$, ZORAN CULIG $^{3}$ and MATTHIAS B. STOPE ${ }^{2,4}$ \\ ${ }^{1}$ Department of Urology, Technische Universität Dresden, Dresden, Germany; \\ ${ }^{2}$ UroFors Consortium (Natural Scientists in Urological Research) \\ of the German Society of Urology, Düsseldorf, Germany; \\ ${ }^{3}$ Experimental Urology, Department of Urology, University of Innsbruck, Innsbruck, Austria; \\ ${ }^{4}$ Department of Gynecology and Gynecological Oncology, University Hospital Bonn, Bonn, Germany
}

\begin{abstract}
Background/Aim: Proinflammatory cytokines play an essential role in the development and progression of prostate cancer $(\mathrm{PCa})$. Especially interleukine (IL-)6 is involved in the development of aggressive PCa. Peripheral blood mononuclear cells (PBMC) have been reported to interact with cancer cells and subsequently lead to increased production of pro-inflammatory cytokines. However, the role of anti-nflammatory cytokines, such as IL-4 is still largely unexplored in prostate cancer. In the present study, we investigated the effects of IL-4 on PBMC co-cultured with PCa cells. Materials and Methods: PBMC were co-culured with the PCa cell lines LNCAP and LNCaP-IL6+. To avoid cell-cell contact, cancer and immune cells were separated using cell culture inserts with a 0.4 um pore size membrane. Cell growth was assessed using the [3-(4, 5-dimethylthiazol2-yl)-2, 5 diphenyl tetrazolium bromide] (MTT) assay. Cytokine levels were measured using a $B D^{T M}$ Cytometric Bead Array. Results: Cell viability of LNCaP cells decreased massively when cells were co-cultured with PBMC. Preincubation with IL-4 could partly rescue the observed effect of cell viability of LNCaP cells co-cultured with PBMC. In contrast, cell viability of the LNCaP-IL6+ cell line was not affected when co-cultured with PBMC. Conclusion: IL-4 counteracts the cytotoxic effects of PBMC on hormonesensitive LNCaP cells and is involved in the immune escape and development of aggressive phenotypes of $P C a$.
\end{abstract}

This article is freely accessible online.

Correspondence to: Matthias Stope, Department of Gynecology and Gynecological Oncology, University Hospital Bonn, VenusbergCampus 1, 53127 Bonn, Germany. Tel: +49 22828711361, Fax: +49 22828716091, e-mail: matthias.stope@ukbonn.de

Key Words: Cancer-related inflammation, pro-inflammatory cytokines, tumour immune escape, IL- $1 \beta$, IL-6, IL-4, TNF- $\alpha$.
Prostate cancer ( $\mathrm{PCa})$ is the most common cancer in elderly men. According to current numbers from the "Globocan 2020" projects, $\mathrm{PCa}$ has the second-highest incidence of all cancers worldwide, with 1,414,259 new cases diagnosed yearly (Europe: 473,344; USA: 239,574 ) and 375,304 yearly deaths related to PCa worldwide (Europe: 108,088; USA: 30.383) (1). As a hormonally driven cancer, androgen-deprivation is the preferred treatment option for initial treatment of locally advanced or metastatic hormone-sensitive PCa. However, hormonal manipulation can facilitate disease progression and development of castration-resistant PCa (CRPC) (2). CRPC is treated with anti-androgens and taxane-based therapies and has improved overall patient survival (3). However, treatment provides only a modest survival advantage due to emergence of complex drug resistance mechanisms (4-6).

Cancer-related inflammation (CRI) can promote or inhibit tumor development, growth, and progression (7). A key role in CRI may be the infiltration of immune cells. During the inflammation process, immune cells are recruited to the tumour and start producing cytokines and inflammatory molecules like reactive oxygen and nitrogen species. However, in $\mathrm{PCa}$, the role of inflammation and infiltrating immune cells is not wellunderstood. A meta-analysis performed on case-control studies showed an association between prostatitis and the risk of $\mathrm{PCa}$ (8). The analysis of clinical data further demonstrated a significant increase of several cytokines in sera of patients with progressive $\mathrm{PCa}(9,10)$. Moreover, peripheral blood mononuclear cells (PBMC) from PCa patients were found to express high levels of inflammation-regulating cytokines, including interleukin (IL)-1, IL-4, IL-6, and tumour necrosis factor $\alpha$ (TNF- $\alpha$ ) in the presence of PCa cells (10-14).

At the cellular level, pro-inflammatory cytokines such as IL- $1 \beta$, IL-6, and TNF- $\alpha$ have been shown to reduce cell growth and proliferation in hormone-sensitive $\mathrm{PCa}$ cell line models LNCaP and LAPC4 $(12,13,15,16)$. On the other hand, these cytokines seem to increase cell proliferation and survival, representing advanced PCa and CRPC. 
A

\section{PCa cells}

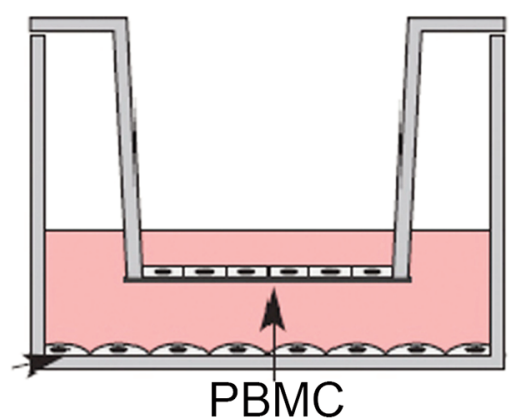

B

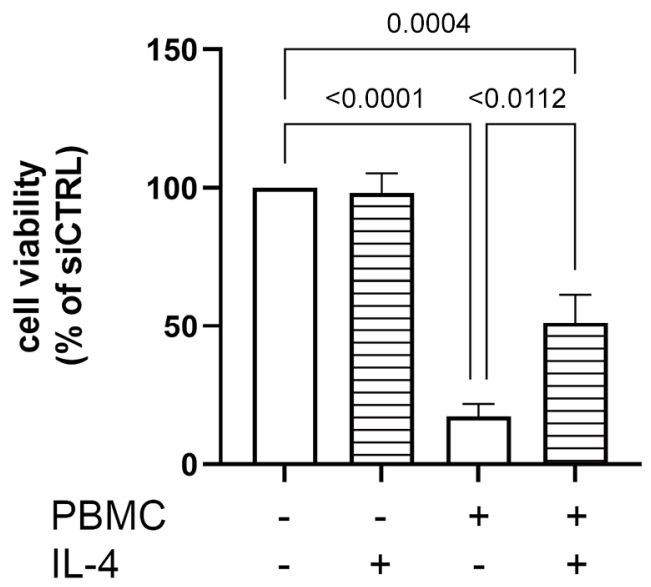

LNCaP IL-6+

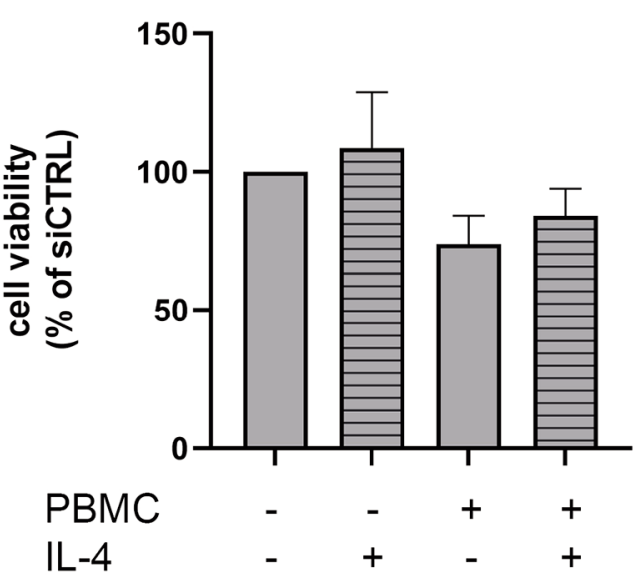

Figure 1. (A) Schematic representation of the experimental setup. Prostate Cancer cells were seeded in 24 well plates. Peripheral blood mononuclear cells $(P B M C)$ of a healthy donor were separated by using cell culture inserts with a 0.4 um pore size membrane. (B) IL-4 counteracts the cytotoxic effects of PBMC on PCa cells. Cell viability of LNCaP and LNCaP IL6+ cells in the co-culture system with PBMC were measured by the MTT assay. As control LNCaP and LNCaP IL6+ cells were cultured without PBMC. The cells were cultured in the prescense and abscense of $10 \mathrm{ng} / \mathrm{ml} I L-4$.

The anti-inflammatory cytokine IL-4 plays a critical role in the regulation of immune response (17). In contrast to proinflammatory cytokines, overexpression of IL-4 resulted in increased AR activity and proliferation of $\mathrm{LNCaP}$ cells $(14,18)$. In PC3 cells, IL-4 induces enrichment of a CD $44^{\text {high }} / \mathrm{CD} 49 \mathrm{~b}^{\text {high }}$ subpopulation with tumour-initiating characteristics and induces PC3 cell proliferation under nutrient-depletion stress $(19,20)$. Moreover, IL-4 enhances the clonogenic potential of PCa stem cell-like cells by activating STAT6 signalling (21).

In the present study, we investigated the physiological effects of IL-4 on PBMC co-cultured with hormone-sensitive and CRPC PCa cells.

\section{Materials and Methods}

Cell lines and cell culture. $\mathrm{LNCaP}$ cells were obtained from the he American Type Culture Collection (ATCC, Rockville, MD, USA). The LNCaP-derived cell line LNCaP IL-6+ was generated by Zoran Culig by continuous treatment of LNCaP cells with $5 \mathrm{ng} / \mathrm{ml} \mathrm{IL-6}$
(Bio-Techne GmbH, Wiesbaden, Germany) (22). LNCaP IL-6+ represents an advanced stage of PCa. The cells were cultured in RPMI 1640 medium (Life Technologies, Darmstadt, Germany) supplemented with 10\% fetal bovine serum (FBS), 20 mM HEPESbuffer, $1 \%$ glutamax, and $1 \%$ penicillin/streptomycin (Fisher Scientific GmbH, Schwerte, Germany). LNCaP IL-6+ were cultured in a medium containing additionally $5 \mathrm{ng} / \mathrm{ml} \mathrm{IL-6.}$

Experimental procedure and IL-4 treatment. To simulate the tumour environment, the cell lines $\mathrm{LNCaP}$ and $\mathrm{LNCaP}$ IL-6+ were cocultured with PBMC of voluntary healthy donors for $72 \mathrm{~h}$. To avoid direct cell-cell contacts and cell cytotoxicity by immune cells, cancer and immune cells were cultured separately using cell culture inserts with a membrane of $0.4 \mu \mathrm{m}$ pore size (Figure 1A). For IL-4 treatment, $10 \mathrm{ng} / \mathrm{ml} \mathrm{IL-4} \mathrm{(R \& D} \mathrm{Systems)} \mathrm{were} \mathrm{added} \mathrm{to} \mathrm{the} \mathrm{cell}$ culture medium for $72 \mathrm{~h}$.

Measurement of cell viability. Cell growth was assessed using the 3-(4,5-dimethylthiazol-2-yl)-2,5-diphenyltetrazolium bromide (MTT) dye reduction assay (Sigma-Aldrich, Darmstadt, Germany). Cells $\left(50 \mu \mathrm{l}, 1 \times 10^{5}\right.$ cells $\left./ \mathrm{ml}\right)$ were seeded onto 96 -well tissue culture 
A

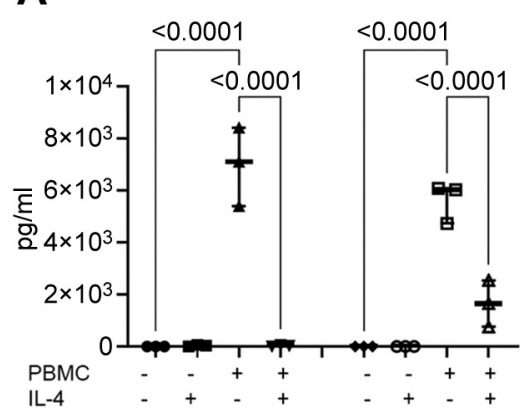

B

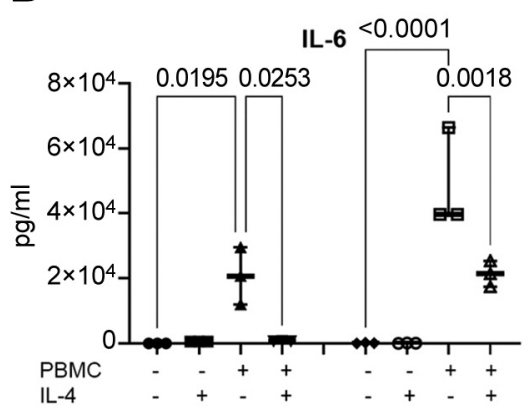

C

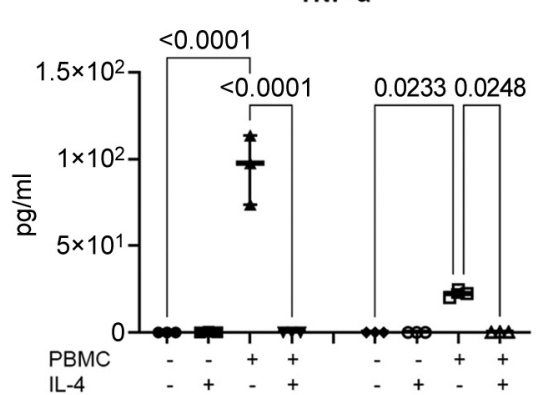

Figure 2. IL-4 reduce the concentrations of pro-inflammatory cytokines in the supernatant of the co-cultured peripheral blood mononuclear cells $(P B M C)$ and prostate caner (PCa) cells. Supernatants of the cell viability experiments were collected at the last day for cytokine mesurment. The cytokines were measured undiluted via BD ${ }^{T M}$ Cytometric Bead Array. The cytokines were measured undiluted via BD ${ }^{T M}$ Cytometric Bead Array.

plates. After 24, 48, and $72 \mathrm{~h}$ MTT $(0.5 \mathrm{mg} / \mathrm{ml})$ was added for additional $4 \mathrm{~h}$. Subsequently, cells were lysed in a buffer containing $10 \%$ SDS in $0.01 \mathrm{M} \mathrm{HCl}$. The plates were incubated overnight at $37^{\circ} \mathrm{C}$ in a humidified, $5 \% \mathrm{CO}_{2}$ incubator. Absorbance at $550 \mathrm{~nm}$ was recorded for each well using a SPARK $10 \mathrm{M}$ Microplate reader (Tecan, Crailsheim, Germany).

Cytokine measurement. The cytokine measurement of IL-1 $\beta$, TNF$\alpha$ was performed by a $\mathrm{BD}^{\mathrm{TM}}$ Cytometric Bead Array (BD Biosciences, Heidelberg, Germany) on a BD FACSCanto ${ }^{\mathrm{TM}}$ II Cell Analyser according to the manufacturer's manual. The obtained data were analysed by FCAP Array Software v3.0 (BD Biosciences). IL6 levels were measured by a Human IL-6 Quantikine ELISA Kit (Bio-Techne $\mathrm{GmbH}$ ) according to the manufacturer's manual.

Statistical analysis. The Prism 9.1 software (GraphPad Software, La Jolla, CA, USA) was used for statistical analyses. One-way ANOVA was used to determine whether data sets were significantly different from each other. Data are presented as mean \pm SEM, or box and whisker. $p$-Values of $\leq 0.05$ were considered significant. All differences highlighted by asterisks were statistically significant as encoded in Figure legends $(* p \leq 0.05 ; * * p \leq 0.01 ; * * * \leq \leq 0.001)$. All experiments were performed in at least three independent biological replicates.

\section{Results}

To assess the impact of PBMC on LNCaP and LNCaP IL-6+ cells, cancer cells were cultured in the co-culture system with PBMC (Figure 1A), and cell viability was measured using the MTT assay. LNCaP and LNCaP IL-6+ cells were cultured without PBMC as a treatment control (Figure 1B). In the presence of PBMC, LNCaP cells showed a significant decrease in cell viability down to $20 \%$ of treatment control. The treatment with $10 \mathrm{ng} / \mathrm{ml} \mathrm{IL-4} \mathrm{did} \mathrm{not} \mathrm{reduce} \mathrm{this} \mathrm{effect.}$ In contrast, LNCaP IL-6+ were not significantly influenced in the presence of PBMC (Figure 1C). Again, treatment with $10 \mathrm{ng} / \mathrm{ml} \mathrm{IL-4}$ had no further effect on the viability of LNCaP IL-6+ cells. These results indicated that PBMC are highly cytotoxic to hormone-sensitive $\mathrm{LNCaP}$ cells and that IL-4 can neutralize this PBMC-mediated toxicity.
Several studies have reported pro-inflammatory cytokines to reduce cell growth and proliferation of hormone-sensitive cell lines including LNCaP cells $(12,13,15,16)$. To investigate if the cytotoxic effects observed in the previous results are due to the influence of pro-inflammatory cytokines, the supernatant of the cell viability experiments were collected after $72 \mathrm{~h}$ of incubation for cytokine measurement. In the absence of PBMC, marginal levels of IL-1 $\beta$ (Figure 2A), IL-6 (Figure 2B), and TNF- $\alpha$ (Figure 2C) could be detected independently of the presence and absence of IL-4. Of all three measured cytokines, IL-6 showed the most substantial increase in co-cultured cell supernatants (Figure 2B). In the presence of PBMC, supernatants of LNCaP and LNCaP IL-6+ cells revealed a significant increase in pro-inflammatory cytokines (Figure 2). This increase of the measured pro-inflammatory cytokines in the co-cultures' supernatant was significantly reduced in the presence of IL-4.

\section{Discussion}

Cytokines are low molecular weight proteins that are involved in communication between cells and control immune response, cell growth, and cell differentiation (13). These proteins exert their effects through autocrine or paracrine signalling and are, therefore, essential for the cross-talk between PCa and the tumour microenvironment. Clinical data showed that several cytokines, e.g. IL-1 $\beta$, IL4, IL-6, and TNF- $\alpha$, are significantly elevated in sera and tumours of patients with progressed PCa $(9,13)$. These cytokines are primarily secreted by cells of the tumour microenvironment, such as tumour-associated stromal cells and tumour-infiltrating immune cells $(13,23)$. Especially, pro-inflammatory cells were shown to be involved in cancer growth and progression (13). For example, increased IL-6 levels have been observed in PCa tissue and are suggested to influence cancer cell growth and survival pathways (24). IL-6 expression levels in PCa tissue also correlate with Gleason score and biochemical recurrence, influence tumour 
initiation, and affect clonogenic recovery after docetaxel treatment of PCa stem-like cells (24-26).

Interestingly, these pro-inflammatory cytokines have been reported to show tumour inhibitory effects in hormonesensitive PCa cell models in vitro and in vivo $(12,13,15,16)$. Similar results could be seen in this study, showing a reduction of cell viability of the hormone-sensitive LNCaP cells in the presence of high concentrations of the proinflammatory cytokines IL- $1 \beta$, IL- 6 , and TNF- $\alpha$ produced by co-cultured PBMC. IL-1 $\beta$ is suggested to decrease proliferation of $\mathrm{LNCaP}$ cells by interaction with the AR signaling (16). In contrast, IL-6 is suggested to induce differentiation processes by activating the STAT3 pathway and therefore cause cell-cycle arrest $(27,28)$. TNF- $\alpha$ mediated growth reduction is suggested to be caused by activation of caspases (15). However, the exact mechanism of decreased cell viability remains unclear due to the lack of cell-cell contacts, paracrine factors, i.e. cytokines and/or reactive oxygen species that can freely pass the membrane of the cell culture's inserts, may be responsible for the decreased viability $(29,30)$. In contrast to the parental LNCaP, the more aggressive LNCaP IL-6+ showed no modulation in cell viability in the presence of PBMC. These results lead to the conclusion that PCa cell lines show a different response to the presence of cytokines depending on their tumour stage.

To date, little is known on the role of anti-inflammatory cytokines in $\mathrm{PCa}$, but several studies have already been able to assign a role to IL-4 in PCa progression $(13,19-21,31)$. IL-4 is a pleiotropic anti-inflammatory cytokine that functions by suppressing the pro-inflammatory milieu (32). This study also demonstrated that IL-4 suppresses the secretion of proinflammatory cytokines IL-1 $\beta$, IL- 6 , and TNF- $\alpha$ by PBMC. As these cytokines have been reported to reduce cell viability and proliferation in LNCaP cells, reducing these cytokines may be one reason for the decrease in cytotoxicity. On the other hand, cytokines IL-1 $\beta$, IL- 6 , and TNF- $\alpha$ have all been reported to be involved in tumor progression and neuroendocrine differentiation, therefore allowing to conclude cytokine dose-dependent effects on cell viability and tumour progression $(28,33,34)$. High concentrations of inflammatory cytokines as found in a cytokine storm are highly toxic to LNCaP cells, whereas reduced cytokine levels promote more aggressive $\mathrm{PCa}$ phenotypes. These aggressive phenotypes are less responsive to cytokines' cytotoxic effects as shown here with the LNCaP IL-6+ cell model.

Based on the data presented in this study, it can be concluded that IL-4 counteracts the cytotoxic effects of PBMC on hormone-sensitive PCa cells and is involved in the immune escape of PCa.

\section{Conflicts of Interest}

The Authors declare that they have no competing interests.

\section{Authors' Contributions}

Conceptualization: H.H.H.E., Z.C., M.B.S.; methodology: H.H.H.E., Z.C., M.B.S.; supervision: Z.C., M.B.S.; writing original draft: H.H.H.E.; original draft review and editing: Z.C., M.B.S.; formal analysis: .H.H.E., Z.C., M.B.S.

\section{Acknowledgements}

This work was funded by the European Union FP7 Marie Curie Initial Training Network PRO-NEST.

\section{References}

1 Sung H, Ferlay J, Siegel RL, Laversanne M, Soerjomataram I, Jemal A and Bray F: Global Cancer Statistics 2020: GLOBOCAN estimates of incidence and mortality worldwide for 36 cancers in 185 countries. CA Cancer J Clin 71(3): 209249, 2021. PMID: 33538338. DOI: 10.3322/caac.21660

2 Mottet N, Bellmunt J, Bolla M, Briers E, Cumberbatch MG, De Santis M, Fossati N, Gross T, Henry AM, Joniau S, Lam TB, Mason MD, Matveev VB, Moldovan PC, van den Bergh RCN, Van den Broeck T, van der Poel HG, van der Kwast TH, Rouvière O, Schoots IG, Wiegel T and Cornford P: EAU-ESTRO-SIOG Guidelines on prostate cancer. Part 1: screening, diagnosis, and local treatment with curative intent. Eur Urol 71(4): 618-629, 2017. PMID: 27568654. DOI: 10.1016/j.eururo.2016.08.003

3 Cornford P, Bellmunt J, Bolla M, Briers E, De Santis M, Gross T, Henry AM, Joniau S, Lam TB, Mason MD, van der Poel HG, van der Kwast TH, Rouvière O, Wiegel T and Mottet N: EAU-ESTROSIOG Guidelines on prostate cancer. Part II: treatment of relapsing, metastatic, and castration-resistant prostate cancer. Eur Urol 71(4): 630-642, 2017. PMID: 27591931. DOI: 10.1016/j.eururo.2016.08.002

4 Tannock IF, de Wit R, Berry WR, Horti J, Pluzanska A, Chi KN, Oudard S, Théodore C, James ND, Turesson I, Rosenthal MA, Eisenberger MA and TAX 327 Investigators: Docetaxel plus prednisone or mitoxantrone plus prednisone for advanced prostate cancer. N Engl J Med 351(15): 1502-1512, 2004. PMID: 15470213. DOI: 10.1056/NEJMoa040720

5 Abazid A, Martin B, Choinowski A, McNeill RV, Brandenburg LO, Ziegler P, Zimmermann U, Burchardt M, Erb H and Stope MB: The androgen receptor antagonist enzalutamide induces apoptosis, dysregulates the heat shock protein system, and diminishes the androgen receptor and estrogen receptor $\beta 1$ expression in prostate cancer cells. J Cell Biochem 120(10): 16711-16722, 2019. PMID: 31297844. DOI: 10.1002/jcb.28929

6 Santer FR, Erb HH and McNeill RV: Therapy escape mechanisms in the malignant prostate. Semin Cancer Biol 35: 133-144, 2015. PMID: 26299608. DOI: 10.1016/j.semcancer.2015.08.005

7 Mantovani A, Allavena P, Sica A and Balkwill F: Cancer-related inflammation. Nature 454(7203): 436-444, 2008. PMID: 18650914. DOI: 10.1038 /nature07205

8 Jiang J, Li J, Yunxia Z, Zhu H, Liu J and Pumill C: The role of prostatitis in prostate cancer: meta-analysis. PLoS One 8(12): e85179, 2013. PMID: 24391995. DOI: 10.1371/journal.pone.0085179

9 Wise GJ, Marella VK, Talluri G and Shirazian D: Cytokine variations in patients with hormone treated prostate cancer. J Urol 164(3 Pt 1): 722-725, 2000. PMID: 10953133. DOI: 10.1097/00005392-200009010-00024 
10 Michalaki V, Syrigos K, Charles P and Waxman J: Serum levels of IL-6 and TNF-alpha correlate with clinicopathological features and patient survival in patients with prostate cancer. $\mathrm{Br}$ J Cancer 90(12): 2312-2316, 2004. PMID: 15150588. DOI: $10.1038 /$ sj.bjc.6601814

11 Salman H, Ori Y, Bergman M, Djaldetti M and Bessler H: Human prostate cancer cells induce inflammatory cytokine secretion by peripheral blood mononuclear cells. Biomed Pharmacother 66(5): 330-333, 2012. PMID: 22739042. DOI: 10.1016/j.biopha.2012.03.004

12 Malinowska K, Neuwirt H, Cavarretta IT, Bektic J, Steiner H, Dietrich H, Moser PL, Fuchs D, Hobisch A and Culig Z: Interleukin-6 stimulation of growth of prostate cancer in vitro and in vivo through activation of the androgen receptor. Endocr Relat Cancer 16(1): 155-169, 2009. PMID: 19011039. DOI: 10.1677/ERC-08-0174

13 Culig Z: Cytokine disbalance in common human cancers. Biochim Biophys Acta 1813(2): 308-314, 2011. PMID: 21167870. DOI: 10.1016/j.bbamcr.2010.12.010

14 Takeshi U, Sadar MD, Suzuki H, Akakura K, Sakamoto S, Shimbo M, Suyama T, Imamoto T, Komiya A, Yukio N and Ichikawa T: Interleukin-4 in patients with prostate cancer. Anticancer Res 25(6C): 4595-4598, 2005. PMID: 16334148.

15 Chopra DP, Menard RE, Januszewski J and Mattingly RR: TNFalpha-mediated apoptosis in normal human prostate epithelial cells and tumor cell lines. Cancer Lett 203(2): 145-154, 2004 PMID: 14732222. DOI: 10.1016/j.canlet.2003.09.016

16 Culig Z, Hobisch A, Herold M, Hittmair A, Thurnher M, Eder IE, Cronauer MV, Rieser C, Ramoner R, Bartsch G, Klocker H and Konwalinka G: Interleukin 1beta mediates the modulatory effects of monocytes on LNCaP human prostate cancer cells. Br J Cancer 78(8): 1004-1011, 1998. PMID: 9792142. DOI: 10.1038/bjc.1998.619

17 Nelms K, Keegan AD, Zamorano J, Ryan JJ and Paul WE: The IL-4 receptor: signaling mechanisms and biologic functions. Annu Rev Immunol 17: 701-738, 1999. PMID: 10358772. DOI: 10.1146/annurev.immunol.17.1.701

18 Lee SO, Pinder E, Chun JY, Lou W, Sun M and Gao AC: Interleukin-4 stimulates androgen-independent growth in LNCaP human prostate cancer cells. Prostate 68(1): 85-91, 2008. PMID: 18008330. DOI: 10.1002/pros.20691

19 Roca H, Craig MJ, Ying C, Varsos ZS, Czarnieski P, Alva AS, Hernandez J, Fuller D, Daignault S, Healy PN and Pienta KJ: IL-4 induces proliferation in prostate cancer PC3 cells under nutrient-depletion stress through the activation of the JNKpathway and survivin up-regulation. J Cell Biochem 113(5): 1569-1580, 2012. PMID: 22174091. DOI: 10.1002/jcb.24025

20 Erb HHH, Guggenberger F, Santer FR and Culig Z: Interleukin4 induces a CD $44_{\text {high }} / \mathrm{CD} 49 \mathrm{~b}_{\text {high }}$ PC3 subpopulation with tumorinitiating characteristics. J Cell Biochem 119(5): 4103-4112, 2018. PMID: 29236307. DOI: 10.1002/jcb.26607

21 Nappo G, Handle F, Santer FR, McNeill RV, Seed RI, Collins AT, Morrone G, Culig Z, Maitland NJ and Erb HHH: The immunosuppressive cytokine interleukin-4 increases the clonogenic potential of prostate stem-like cells by activation of STAT6 signalling. Oncogenesis 6(5): e342, 2017. PMID: 28553931. DOI: 10.1038/oncsis.2017.23

22 Hobisch A, Ramoner R, Fuchs D, Godoy-Tundidor S, Bartsch $\mathrm{G}$, Klocker $\mathrm{H}$ and Culig Z: Prostate cancer cells (LNCaP) generated after long-term interleukin 6 (IL-6) treatment express
IL-6 and acquire an IL-6 partially resistant phenotype. Clin Cancer Res 7(9): 2941-2948, 2001. PMID: 11555613.

23 Conticello C, Pedini F, Zeuner A, Patti M, Zerilli M, Stassi G, Messina A, Peschle C and De Maria R: IL-4 protects tumor cells from anti-CD95 and chemotherapeutic agents via up-regulation of antiapoptotic proteins. J Immunol 172(9): 5467-5477, 2004. PMID: 15100288. DOI: 10.4049/jimmunol.172.9.5467

24 Culig Z and Puhr M: Interleukin-6: a multifunctional targetable cytokine in human prostate cancer. Mol Cell Endocrinol 360(1-2): 52-58, 2012. PMID: 21664423. DOI: 10.1016/j.mce.2011.05.033

25 Ishiguro H, Akimoto K, Nagashima Y, Kagawa E, Sasaki T, Sano JY, Takagawa R, Fujinami K, Sasaki K, Aoki I, Ohno S, Kubota Y and Uemura H: Coexpression of aPKC $\lambda / \mathrm{L}$ and IL-6 in prostate cancer tissue correlates with biochemical recurrence. Cancer Sci 102(8): 1576-1581, 2011. PMID: 21535317. DOI: 10.1111/j.1349-7006.2011.01972.x

26 Kroon P, Berry PA, Stower MJ, Rodrigues G, Mann VM, Simms M, Bhasin D, Chettiar S, Li C, Li PK, Maitland NJ and Collins AT: JAK-STAT blockade inhibits tumor initiation and clonogenic recovery of prostate cancer stem-like cells. Cancer Res 73(16): 5288-5298, 2013. PMID: 23824741. DOI: 10.1158/00085472.CAN-13-0874

27 Spiotto MT and Chung TD: STAT3 mediates IL-6-induced neuroendocrine differentiation in prostate cancer cells. Prostate 42(3): 186-195, 2000. PMID: 10639189. DOI: 10.1002/ (sici)1097-0045(20000215)42:3<186::aid-pros4>3.0.co;2-e

28 Zhu Y, Liu C, Cui Y, Nadiminty N, Lou W and Gao AC: Interleukin-6 induces neuroendocrine differentiation (NED) through suppression of RE-1 silencing transcription factor (REST). Prostate 74(11): 1086-1094, 2014. PMID: 24819501. DOI: $10.1002 /$ pros.22819

29 Weiss M, Gümbel D, Gelbrich N, Brandenburg LO, Mandelkow R, Zimmermann U, Ziegler P, Burchardt $\mathrm{M}$ and Stope MB: Inhibition of cell growth of the prostate cancer cell model LNCaP by cold atmospheric plasma. In Vivo 29(5): 611-616, 2015. PMID: 26359422.

30 Yang Y, Bazhin AV, Werner J and Karakhanova S: Reactive oxygen species in the immune system. Int Rev Immunol 32(3): 249-270, 2013. PMID: 23617726. DOI: 10.3109/08830185.2012.755176

31 Das S, Roth CP, Wasson LM and Vishwanatha JK: Signal transducer and activator of transcription-6 (STAT6) is a constitutively expressed survival factor in human prostate cancer. Prostate 67(14): 1550-1564, 2007. PMID: 17705178. DOI: $10.1002 /$ pros. 20640

32 Opal SM and DePalo VA: Anti-inflammatory cytokines. Chest 117(4): 1162-1172, 2000. PMID: 10767254. DOI: 10.1378/ chest.117.4.1162

33 Grigore AD, Ben-Jacob E and Farach-Carson MC: Prostate cancer and neuroendocrine differentiation: more neuronal, less endocrine? Front Oncol 5: 37, 2015. PMID: 25785244. DOI: $10.3389 /$ fonc .2015 .00037

34 Haley KJ, Patidar K, Zhang F, Emanuel RL and Sunday ME: Tumor necrosis factor induces neuroendocrine differentiation in small cell lung cancer cell lines. Am J Physiol 275(2): L311-L321, 1998. PMID: 9700092. DOI: 10.1152/ajplung.1998.275.2.L311

Received April 12, 2021

Revised April 29, 2021

Accepted May 18, 2021 